\title{
HAZAI ÜZEMELŐ ÉS TÁVLATI PARTI SZÜRÉSŰ IVÓVÍZBÁZISOK MENNYISÉGI ÉS MINŐSÉGI ÉRTÉKELÉSE
}

\author{
QUALITATIVE AND QUANTITATIVE ASSESMENT OF HUNGARIAN OPERATING \\ AND PERSPECTIVE BANK FILTRATION WATER SOURCES
}

\author{
GODA Zoltán; \\ (ORCID: 0000-0002-4164-473X); \\ goda.zoltan@uni-nke.hu;
}

\begin{abstract}
Absztrakt
Hazánk ivóvíztermelésének több, mint 30\%-a üzemelö parti szürésü ivóvízbázisokból származik és a legjelentősebb távlati ivóvízbázisok is folyóink homokos-kavicsos teraszain kerültek kijelölésre. A parti szürésü vízszerzés mindmáig az egyik leghatékonyabbnak és leggazdaságosabbnak tekinthető, más vízszerzési módokkal összehasonlítva számos elönnyel rendelkezik. A parti szürésü vízbázisok szürörétegében végbemenő mechanikai, biológiai és fizikaikémiai folyamatok természetes úton zajlanak le, ezáltal jelentős költségek takarithatók meg. A szerző e cikkben rámutat a parti szürés folyamatainak máig ismeretlen területeire, veszélyeztető tényezőire, valamint arra a tényre, hogy az elmúlt két évtizedben sérülékenynek minősitett és részben védelembe helyezett parti szürésü vízbázisaink mennyiségi és minőségi mutatóinak figyelemmel követése és monitorozása kiemelt jelentőséggel bír, hiszen vízellátásunk jelentős pillérét képezik. A parti szürésü vízbázisok értékelésén túl a szerző rávilágít a vízbázisvédelem hiányosságaira, valamint felhívja a figyelmet új, napjainkban jelentkező kockázati tényezőkre.
\end{abstract}

Kulcsszavak: parti szürés, vízbázisvédelem, vízbiztonság

\begin{abstract}
More than 30\% of Hungarian drinking water production is derived from bank filtration wells and the most important long-term drinking water sources have been designated on sandgravel fluvial terraces. Bank-filtrated water production is one of the most effective and economical method, with many benefits compared to other water treatments. In case of the bank filtrated water resources the mechanical, biological and physical-chemical processes in the filtration layer run in natural way, thus saving significant operational costs. In this article, the author points out the still unknown areas of the bank filtration processes and the fact that the monitoring of quantitative and qualitative indicators of our water resources that have been classified as vulnerable and partially protected in the last two decades are important since our water supply's significant pillar. In addition to evaluating bank-filtered water resources, the author highlights the shortcomings of water source protection and draws attention to new, present-day risk factors.
\end{abstract}

Keywords: bank filtration, water source protection, water safety

A kézirat benyújtásának dátuma (Date of the submission): 2019.03.14. A kézirat elfogadásának dátuma (Date of the acceptance): 2019.05.08. 


\section{BEVEZETÉS}

Hazánk ivóvízellátását közel kétezer ivóvízbázis biztosítja, amelyek jelentős többsége felszín alatti vízbázis. Ebbe a csoportba tartoznak a karszt-, réteg-, és talajvízbázisok mellett a parti szürésű vízbázisaink is, melyeket nagyobb folyóink mentén, azok homokos-kavicsos teraszain találunk meg. A hazai ivóvízellátásban jelentős szerepet játszanak és figyelembe véve, hogy a parti szürésü vízadókból kitermelhető víz mennyiségileg és minőségileg is kiválónak tekinthető, várhatóan a jövőben is inkább e vízbázisokat részesítjük majd előnyben. Ezt jól mutatja, hogy a kijelölésre került távlati vízbázisaink szinte kivétel nélkül parti szürésü vízbázisok.

Fontos azonban látnunk, hogy parti szürésű vízbázisaink kivétel nélkül külső ártalmaktól veszélyeztetett, sérülékeny vízbázisnak minősülnek, így védelemben tartásuk kiemelt feladat kell legyen. A vonatkozó kormányrendeletben foglaltak alapján a sérülékeny ivóvízbázisok diagnosztikája és védelembe helyezése sok esetben már megtörtént, de fontos, hogy ezt a védelmet - tulajdonképpen egy véget nem érő folyamatként - fenntartsuk.

Ebben a cikkben a parti szürésü vízbázisok hazai jelentőségének hangsúlyozása mellett rámutatok azokra a tényezőkre, amelyek a vízbázis zavartalan müködését veszélyeztetik, illetve olyan kevésbé ismert környezeti hatásokra, amelyekkel a jövőben várhatóan számolnunk kell. Bemutatom a védelembe helyezés jelenlegi állapotát és hiányosságait, továbbá javaslatot teszek a védelem kiegészítésének lehetséges módszereire.

\section{A PARTI SZŰRÉS KÜLÖNLEGESSÉGE}

A parti szürés fogalmát mindmáig nem sikerült teljesen egzakt módon meghatározni. Különböző aspektusból vizsgálva más-más szempontokat kihangsúlyozva némiképpen különböző definíciókat kaphatunk. Leszögezhetjük, hogy a felszíni víz - legtöbb esetben egy folyó vize - egy jó vízvezető képességü üledékes kavicsrétegen, a mederágyon átszürődve jut el a víztermelő kútba. A folyó vizének a mederágyba történő beszivárgása és a kút irányába történö áramlása a víztermelés hatására következik be. (1. ábra)

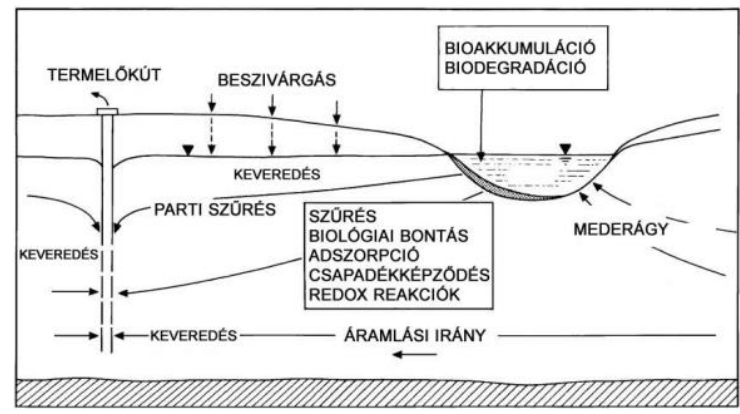

1. ábra A parti szürés folyamatai (Hiscock és Grischek nyomán) [1]

Ez a mesterségesen létrehozott áramlás a vízbázisból kitermelt víz mennyiségének függvényében határozza meg a szivárgási időt, amely a parti szürés folyamatának lényeges tényezője A szivárgás során főleg mechanikai, fizikai-kémiai és biológiai folyamatok zajlanak, amelyek következtében többek között a felszíni víz lebegö-, és szervesanyag-tartalma csökken jelentős mértékben, valamint mikrobiológiai paraméterei akár több nagyságrenddel is javulhatnak. A szivárgás során a mederágy adottságainak függvényében a folyó vize változó arányban keveredik a felszín alatti vízzel, így a víztermelö kútból kitermelhető nyersvíz tulajdonképpen e kettő keveréke. A vonatkozó kormányrendelet alapján a szürt folyóvíz aránya a termelt vízben legalább 50\% kell legyen, de az elmúlt évtizedekben elvégzett oxigén-, és 
hidrogénizotópos vizsgálatok is alátámasztják, hogy ez az arány vízállástól és mederanyagtól függően $60 \%$ és $95 \%$ között változhat. [2] [3]

Évtizedek tapasztalatai azt mutatják, hogy szerencsés, ha a szürt folyóvíz aránya lényegesen nagyobb a felszín alatti víz (ún. háttérvíz) arányához képest. Ez utóbbi általában határérték feletti vas és mangántartalommal, esetenként nitrogénformákkal szennyezett, így ilyen esetben kiegészítő vízkezelési technológia üzemeltetése elengedhetetlen. Egy jól működő, magas szürt víz aránnyal rendelkező parti szürésü kút vize akár az ivóvízszabványnak megfelelö paraméterekkel termelhető ki, azaz közvetlen fogyasztásra is alkalmas lehet. Ilyen arány elérése legtöbbször csak szigeten létesített ivóvízbázison lehetséges, ahol minden irányból parti szürt víz áramlik a kútba, a háttérvíz aránya pedig minimális. Az ilyen kútból termelt nyersvíz gyakorlatilag ivóvíznek tekinthető és utófertőtlenítés után az ivóvízhálózatba továbbítható. Az utófertőtlenítésre a kiterjedt ivóvízhálózatok miatt van szükség, ahol a tartózkodási idő néhány órától egy-két napig is terjedhet, de ezalatt az ivóvíz megfelelő állapotát egészen a fogyasztóig fenn kell tartani.

Fontos leszögezni, hogy a vízbázisból kitermelt víz mennyisége által jelentősen befolyásolt szivárgási időnek meghatározható egy ideális tartománya. Túl gyors szivárgási sebesség esetén a várt folyamatok nem zajlanak le teljes mértékben és a felszíni vízre jellemző szennyezések elérhetik a termelőkutat. Az ideálisnál lényegesen hosszabb szivárgási idő esetén pedig a víz tartósan anaerob állapotba kerül és e körülmények között nem kívánt kémiai folyamatok zajlanak le. Ilyen reakció a már oxidált állapotban lévő vas visszaoldódása, amely koncentrációja így a kút nyersvizében megemelkedik, ez pedig további vízkezelési lépéseket tesz szükségessé.

Felismerve azt a tényt, hogy a parti szürésü kút által termelt nyersvíz más típusú felszín alatti vizekkel összehasonlítva lényegesen alacsonyabb üzemi költségek árán alakítható ivóvízzé, a parti szürésü vízszerzés hazánkban és a világ más országaiban is gyakran, jelentős arányban alkalmazott módszer.

\section{PARTI SZŰRÉSŰ VÍZBÁZISOK HAZAI JELENTŐSÉGE}

Az elmúlt néhány évtized jelentős változásokat hozott a vízszerzés területén. A változás főleg mennyiségi, hiszen a globális vízfogyasztási ráta szignifikáns emelkedésével szemben a hazai vízfogyasztási adatok folyamatos csökkenő tendenciát jeleznek.[4] A csökkenő tendencia állandónak mondható, de a 90-es évek fordulóján az átlagosnál is határozottabb mértékü fogyasztáscsökkenés következett be. A 80-as évek elején feljegyzett adatok napi 4 millió $\mathrm{m}^{3}$ víz termelését rögzítették, ez az érték 2016-ban 1.950.000 $\mathrm{m}^{3}$ volt.

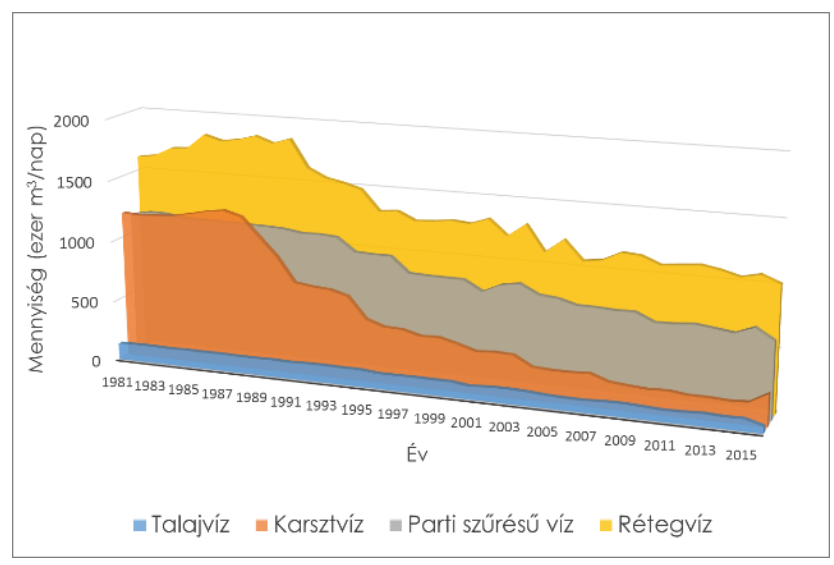

2. ábra Az egyes felszín alatti víztípusok termelésének tendenciái (1981-2016) [4] 
Számszerủ adatainkból az is látható, hogy a parti szürésü vízbázisok teljes vízszerzésen belüli aránya kimutathatóan emelkedett. Összehasonlítva a 80-as évek elejéröl gyüjtött vízszerzési adatokat a jelenlegi értékekkel azt láthatjuk, hogy amíg a karsztvíz és rétegvíz készletek kitermelése jelentősen csökkent, addig a parti szürésü víz használata lassú és egyenletes csökkenést mutatott. Ennek oka a rendszerváltás időszakában bekövetkezett ipari átalakulásban keresendő, hiszen amíg a karszt-, és rétegvíz termelése ebben a szektorban volt kiemelkedő, addig a parti szürésủ víz felhasználása mindmáig a lakossági vízellátásban - ide értve Budapest teljes vízellátását - játszik szerepet. Az ipar átalakulásával a rétegvíztermelés jelentős csökkenést mutatott, a karsztvíz termelése pedig a bányászati tevékenység jelentős visszaesésével párhuzamosan a töredékére csökkent. Természetesen a víztermelés alakulásában meghatározó szerepet játszott a víz díjszabásának emelkedése is, amely előtérbe helyezte a takarékoskodás szempontját. Ennek következtében az üzemelö parti szürésü vízbázisok aránya az elmúlt közel negyven évben 27\%-ról 32\%-ra emelkedett. Fontosnak tartom, hogy rámutassak arra a tényre is, hogy a távlati vízbázisok - azaz jelenleg nem üzemeltetett, de kijelölt és védelembe helyezett jó vízadók - jelentős többsége parti szürésű vízbázis. A teljes vízszerzést, azaz az üzemelő és távlati vízbázisokat is megjelenítő grafikonból látható, hogy a parti szürésü vízbázisok összesen 52\%-át teszik ki a hazai vízbázisainknak. (3. ábra)

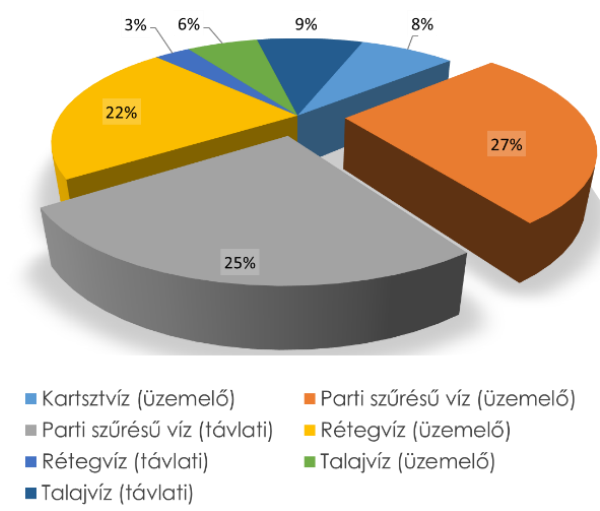

3. ábra Hazai üzemelő és távlati vízbázisok aránya 2016. [4]

A csökkenő fogyasztási ráta mellett tehát a parti szürésü vízbázisok aránya emelkedett, azaz a korábbinál is nagyobb mértékben támaszkodunk rájuk. Az elmúlt évtizedek során távlati vízbázisaink kijelölése mellett üzemelő vízadó is létesült, e cikk írása előtt nem sokkal Szekszárd város új vízbázisának üzembe helyezése történt meg.

\section{VÍZBÁZIS DIAGNOSZTIKA}

Az utóbbi évek technikai fejlődése a vízbázis diagnosztika területén is számottevő elörelépést hozott. Részben a vízbázisvédelmi törekvéseknek, részben pedig a témában folyó kutatásoknak köszönhetően a korábbiaknál részletesebb állapotfelmérés készült parti szürésű vízbázisaink esetében is. A kutatófúrásokból gyüjtött adatokra támaszkodó hidraulikai modellezés, valamint a kiépült felszín alatti víz monitoringrendszer vízminőségi és vízszint adatsorai információval szolgálnak a vízbázisok kiterjedéséről, állapotáról és változásairól. A vízbázisok, távlati vízbázisok, valamint az ivóvízellátást szolgáló vízilétesítmények védelméről szóló 123/1997. (VII. 18.) Kormányrendelet a vízbázis-diagnosztika során gyüjtött adatokra alapozva védőidom, belső és külső, valamint hidrogeológiai védőövezetek kijelölését írja elő.[2] E védőövezetek a védelem céljával összefüggő és a terület használatával kapcsolatos korlátozások szempontjából egységes rendszert alkotnak. A kormányrendelet pontosan szabályozza, hogy az egyes védőövezeteken belül milyen tevékenység folytatható és melyek azok, amelyek nem emgedélyezhetők. 
Az elöírt diagnosztikai felméréstől függetlenül több vízbázis esetén környezeti izotópos szivárgás vizsgálat zajlott, amelynek köszönhetően hiteles információt szerezhettünk a kutak nyersvizének szürt víz-háttérvíz arányáról. Az oxigénizotóp $\left(\delta^{18} \mathrm{O}\right)$, a deutérium $\left(\delta^{2} \mathrm{H}\right)$ és a trícium $\left({ }^{3} \mathrm{H}\right)$ koncentrációjának vizsgálata történt meg többek között a Szentendrei-sziget és a Szigetköz parti szürésü vízbázisain. Az eredmények rámutatnak, hogy az adott folyó (esetünkben a Duna) pillanatnyi vízállása jelentősen befolyásolja ezt az arányt, így a szürt víz arány tág határok között (60-95\%) mozog. Ezt az eredményt értékelve azt a következtetést kaphatjuk, hogy a kutak nyersvizének vízminőségi mutatói sem állandó értékek, ezt pedig érdemes lenne az egyes vízkezelési technológiák irányításába input adatként beemelni. Mivel a vízbázis diagnosztikai információk első sorban modellezésen alapulnak, fontos lenne minden vízbázis esetén - ide értve a távlati vízbázisokat is - környezeti izotópos vizsgálatokat lefolytatni. A védelembe helyezés időszaka óta ugyanis átfogó, részletezö, illetve az esetleges változásokat követő kutatások vízbázisainkon nem történtek. Az eltelt évtizedekben lezajlott méréstechnikai fejlődés, valamint a vízbázisokon vélhetően bekövetkezett hidromorfológiai változások indokolják a diagnosztikai vizsgálatok folytatását, kiegészítését.

Parti szürésü vízbázisainkra hajlamosak vagyunk úgy tekinteni, mint egy természetes folyamatokon alapuló, stabil és végtelen kapacitású víztermelő gépezetre. A korábban részletezett vízminőségi okok miatt preferált parti szürésü vízbázisok kapcsán azonban számos veszélyeztető tényezőre érdemes felhívni a figyelmet, amelyek miatt kivétel nélkül „sérülékeny” kategóriába kerültek besorolásra.

\section{VESZÉLYEZTETŐ TÉNYEZŐK ÉS VÍZBIZTONSÁG}

Különleges helyzetükből adódóan a parti szürésű vízbázisokat számos környezeti hatás veszélyezteti. Sérülékenysége szempontjából is kakukktojásnak tekinthetők, hiszen amíg egy réteg-, karszt-, vagy talajvízbázis esetében egy szennyezőforrás a vízbázison, vagy annak környezetében jelent kockázatot, addig egy parti szürésủ vízbázis esetében egy, a folyó mentén elhelyezkedő, de a vízbázistól több száz kilométerre lévő szennyezőforrás is kockázati tényező lehet. Elegendő csupán a közelmúltbéli ajkai vörösiszap-katasztrófára gondolni, ahol a Torna patakba ömlő erősen lúgos vörösiszap egy része a Marcal és a Rába folyókon, valamint a Mosoni-Dunán haladva elérte a Duna Budapest feletti, valamint a fővárosi vízbázisait. Az ilyen havária-jellegü események lefolyása igen gyors, a szennyezőanyagok összetétele és koncentrációja tág határok között változhat, éppen ezért szinte lehetetlen hatékonyan felkészülni rájuk. Egyes szennyezőanyagok - föleg szerves és szervetlen mikroszennyezők - a mederfalon át, lényegesebb koncentráció-csökkenés nélkül érhetik el a kutat, így egy ilyen jellegü szennyezés komoly kockázatot hordoz magában.

Folyóink vízminősége nagymértékben függ az országhatáron túli hatásoktól. Néhány vízfolyást kivéve (Zala, Sió-csatorna) folyóink vízgyüjtőjének jelentős része határainkon kívüli területeken található, így kitettségünk a külföldröl érkező szennyezésekkel szemben nem elhanyagolható, fokozott figyelmet igényel. [5]

Hasonlóan kiemelt figyelmet érdemel az a tény, hogy folyóinkat nem csupán vízszerzésre, hanem szennyvizek, szerencsésebb esetben tisztított szennyvizek befogadójaként is használjuk. A szennyvizek folyókba történő bevezetése permanens és pontszerü szennyezőforrásnak tekinthető, ahol a kémiai-mikrobiológiai összetétel általában ismert. Elmondható, hogy hazánkban és a Duna-menti országokban az elmúlt évtizedekben jelentősen növekedett a tisztított szennyvizek aránya, számos biológiai fokozattal üzemelő tisztítótelep létesült, így a befogadók szervesanyag-terhelése határozottan csökkent. A szerves és szervetlen mikroszennyezők (peszticidek, gyógyszermaradványok, hormonok) - amelyek eltávolításában a parti szürés nem tekinthető megfelelő hatékonyságúnak - általában alacsony koncentrációban fordulnak elő jelentősebb vízhozamú folyóinkban, de jelenlétünkre, illetve a terület kutatására figyelmet kell fordítanunk. 
A folyami közlekedés hatása kettős. Egyrészt a hajók üzemanyag-felhasználása jelent állandó, mozgó, de pontszerünek tekinthető szennyezőforrást, amely általában változó vízoldhatóságú mikroszennyezők, kőolajszármazékok jelenlétét okozza. Bár a kőolajszármazékok jelentős része a víznél könnyebb fajsúlyú, így egy olajszennyezés a felszínen vonul le, fontos megjegyezni, hogy egyes összetevői vízoldhatók, így a víztesten keresztül bejuthatnak a parti szürésű vízbázisba is. Talán ezen a téren is pozitív változást vélelmezhetünk a hajómotorok korszerüsítése, fogyasztásuk csökkentése, az üzemanyagok hatékonyabb elégetése és a szigorúbb biztonsági elöírások révén. A teherhajók rakományát tekintve igencsak változatos képet kapunk, a fütőanyagoktól kezdve a kőolajszármazékokon át, a magas szervesanyag-tartalmú árukig sokféle szállítmány forgalma történik. Ezek baleset során kerülhetnek a folyó vizébe, de természetesen egy esetleges szerencsétlenség helyszíne, illetve a folyóba jutó szennyezőanyag mennyisége, valamint a kibocsátás intenzitása nem tervezhető tényező.

A folyamszabályozás parti szürésű vízszerzésre gyakorolt kétségtelen előnye, hogy a legtöbbször külső, azaz a víz által mosott partélre telepített kutak védelmét is szolgálja. Védelmi létesítmények - általában a parttal párhuzamosan kialakított kőszórások, illetve arra merőleges sarkantyúk - hiányában a folyó eróziója, illetve abráziója következtében a mederfal instabil maradna, így a vízbázisra telepített kutak, kútcsoportok gyors ütemben károsodnának. Ilyen, a parti szürésü vízbázisokat is érintő létesítmények legföképpen a Duna mentén találhatók. Fontos azonban felhívni a figyelmet arra a tényre, hogy a folyamszabályozás kezdete óta eltelt időszakban a Duna medrének mozgása nem szünt meg, csak megváltozott. A korábbi, folyókra általában jellemző meanderező mozgás teljesen megszünt, ezzel szemben a meder kimutatható süllyedése következett be. (4. ábra) A Duna medre átlagosan mintegy $100 \mathrm{~cm}$-t mélyült a szabályozás óta, azaz morfológiailag átalakult, ez a változás pedig nem szünt meg, napjainkban is zajlik.

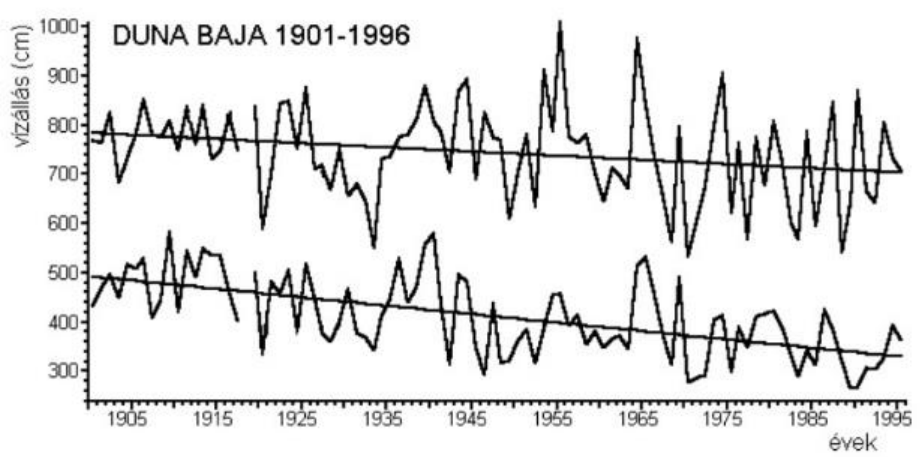

4. ábra A Duna bajai éves közepes és maximális vízállásainak lineáris trendjei. [4]

Jelenleg nincsenek kielégítő ismereteink és kutatási eredményeink arra vonatkozóan, hogy a medersüllyedés hatására hogyan változik meg a mederfal hidraulikája és az érintett vízbázisokra jellemző áramlási viszonyokra mindez milyen hatással van. Ez fontos kutatási terület lehet, hiszen a folyamszabályozás, a Duna hajózhatóságának fenntartása napjainkban is kiemelten kezelt téma és bár az erről szóló tanulmányok természetesen figyelembe veszik a parti szürésü vízbázisok helyzetét, a meder esetlegesen bekövetkezett morfológiai változásaival csupán érintőlegesen és általánosságban foglalkoznak.

A parti szürés jól leírt jelensége a kolmatáció. A jelenség a mederágy szivárgási útjainak eltömődését jelenti. Megkülönböztetünk fizikai kolmatációt, amely esetben a vízzel együtt beszivárgó apró agyag-, és iszapszemcsék tömítik el a szivárogtatásban szerepet játszó térrészt, illetve kialakul biológiai kolmatáció is, amikor a felszaporodó biofilm okozza az eltömődést. Eddigi ismereteink alapján a kolmatált réteg vastagsága mindössze néhány centiméter, a réteg pedig közvetlenül a mederfal vízzel érintkező oldalán helyezkedik el.[1] Habár a jelenség 
kapcsán számos kutatás született, kialakulásával kapcsolatosan sok tényező mindmáig tisztázatlan. Nem ismerjük pontosan, hogy az adott vízbázis kiterjedése, hidromorfológiai tulajdonságai, a vízfolyás lebegő-, és szervesanyag tartalma, valamint a termelt víz mennyisége hogyan befolyásolja a kolmatált felület kiterjedését, vastagságát. Arról is csupán hiányos ismereteink vannak, hogy a kolmatáció kialakulása után hogyan változnak meg az áramlási viszonyok a mederágy rétegein belül. A kolmatáció kapcsán a legkevesebb tapasztalattal a lebontási folyamatokban szerepet játszó biofilm genomikai összetétele, viselkedése, pusztulása és bomlási folyamatai kapcsán rendelkezünk.

A biofilm képzödését laborkörülmények között is sikerült megfigyelnünk. A parti szürés folyamatait modellező lassú homokszürő felületén több hónapnyi folyamatos müködés során néhány centiméter vastagságban kialakult biofilm a homokszürőben mért nyomásesésből és annak változásából már üzem alatt is valószínüsíthető volt. A szürő víztelenítését követően pedig vizuálisan is sikerült megfigyelnünk. (5. ábra)

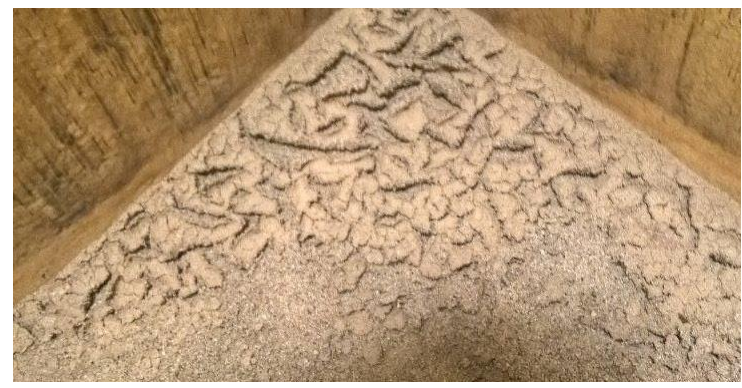

5. ábra Homokszürő felületén kialakult komatálódott biofilm a szürő víztelenítését követően [6]

A klímaváltozás hatása felszín alatti ivóvízbázisainkra nem mondható egységesnek, de a legfrissebb kutatások eredményei alapján elmondható, hogy a vízbázisok utánpótlódásának csökkenésével mindenképpen számolnunk kell.[7] A csapadék éves eloszlása, mennyisége jelentősen változik, szélsőségesebbé válik. A vízbázis minőségi és mennyiségi mutatóinak változatlanságához a kiegyenlített csapadékviszonyokat tekintjük ideálisnak. Tapasztalataink azonban arra mutatnak rá, hogy a hirtelen, nagy tömegben lehulló csapadéknak éppúgy fennáll a veszélye, mint a tartós, száraz, aszályos időszakoknak. [8] A szélsőségesen alakuló csapadékbeszivárgás nem csak mennyiségi, hanem minőségi problémákat is okozhat a parti szürésű vízbázisokon. Eddigi kutatásaimból kiderült, hogy - amennyiben a vízbázis a part mentén és nem szigeten található - a folyó vízszintjének csökkenésével a partfalon átszürt felszíni víz aránya csökken a kutakban, ami természetesen azt jelenti, hogy a háttérvíz aránya emelkedik, így növekszik a talaj-, és rétegvizekre jellemző oldott vas, mangán és ammónium koncentrációja a kitermelt nyersvízben. Ez a jelenség hosszú távon a vízkezelési technológia átalakítását, nagyobb vegyszer-, és energiaigényt jelenthet.

Az elmúlt néhány évtizedben a Duna átlagos hőmérséklete $1{ }^{\circ} \mathrm{C}$-ot, emelkedett, de ez az emelkedés augusztus hónapban megközelíti az $5{ }^{\circ} \mathrm{C}$-ot. Tulajdonképpen semmi információval nem rendelkezünk arról, hogy ez a hömérséklet-emelkedés hogyan hat a folyó ökoszisztémájára, hogyan befolyásolja a mederfalon kialakuló biofilm müködését és az ott zajló, elsősorban biológiai folyamatokat. Fontos tehát látnunk, hogy a klímaváltozás parti szürésü vízbázisainkra gyakorolt hatását vizsgálva nagyon kevés információval rendelkezünk, hiszen magát a klímaváltozás jelenségét sem ismerjük eléggé. Fel kell készülnünk elsősorban a szélsőséges csapadékviszonyok és az emelkedő vízhőmérséklet által okozott problémák kezelésére. 


\section{HIÁNYOS VÉDELEM}

A 123/1997. (VII. 18.) Kormányrendelet alapján az üzemelő és távlati vízbázisaink stratégiai fontosságúak, így a külső ártalmaktól védendők, a környezetüknél fokozottabb biztonságban tartandók. A kormányrendelet kiadását követő két évtizedben a vízbázisok diagnosztikai vizsgálatai, majd védelembe helyezésük részben megtörtént, ám egyes területeken a folyamat a mai napig nem zárult le. Vízbázisaink környezetének védelmét az üzemeltetőkkel együttmüködve szakhatóság látja el, a védőövezetekre telepített vízminőségi monitoringrendszer pedig információval szolgál az esetleges változásokról, a vízbázist veszélyeztető szennyezőanyagok megjelenéséről, terjedéséről.

A védelembe helyezés módszertana azonban nem tett lényeges különbséget a parti szürésü vízbázisok és a többi felszín alatti vízbázis között. Éppen a leglényegesebb különbség, azaz a felszíni víztest közelsége indokolná az eltérő szemléletet, azonban a diagnosztikai fázisban meghatározott védöövezetek mederoldali része, csupán a modellezésen alapuló beszivárgási jellemzők alapján kerültek meghatározásra. Kiemelten fontosnak tartom a mederoldali védelem újragondolását, különösen, hogy a váratlan és gyors lefolyású szennyezések ebből az irányból érhetik el a vízbázist.

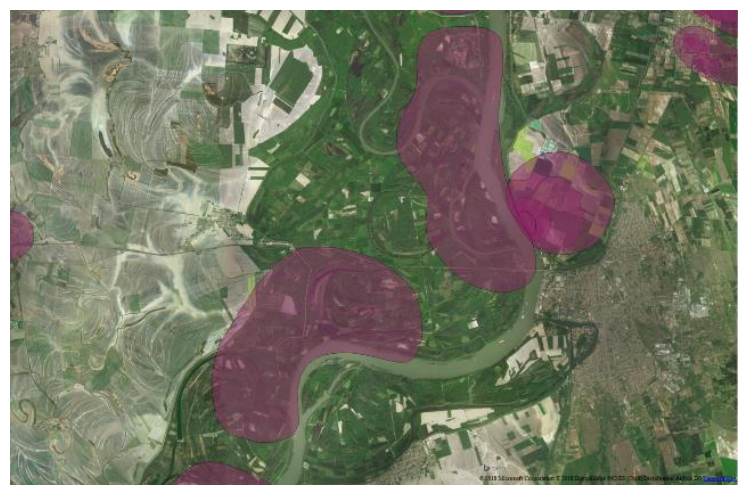

6. ábra Baja város környezetében kijelölt üzemelö és távlati parti szürésü vízbázisok [9]

Az egyes vízbázisok védelembe helyezési dokumentációja tartalmazza a védterületen megtalálható szennyezőforrások adatait, kiterjedését, kockázati faktorait. Modellezéssel meghatározásra kerültek az elérési idők alapján számított védöövezetek határai is. A mederoldali védelem azonban gyakorlatilag hiányzik.

A víztermelő létesítmény üzemeltetője, mint a vízbázis kezelöje köteles a védőövezeteken belüli területeket évente ellenőrizni és a kezelésébe adott monitoring kutakból az elöírt gyakorisággal vízmintát venni. Az így gyüjtött adatok alapján összeállított dokumentációt 10 évente a szakhatóság felé be kell nyújtni. A védelemben tartásnak azonban nem lettek meghatározva további lépései, így a gyakorlatban vízminőségi adatsorok gyüjtésén kívül más tevékenység nem történik.

\section{KÖVETKEZTETÉSEK}

Magyarország kétségtelenül jelentős felszín alatti víztartalékokkal rendelkezik. Csak a parti szürésü vízbázisokra fókuszálva az elérhető és kitermelhető kapacitás nagyjából háromszorosa a jelenlegi vízigénynek. Ismerve csökkenő vízfogyasztási adatainkat látszólag hatalmas stratégiai tartalékokat kezelünk. Ezen vízbázisaink kihasználtságának növekedése a jövőben csak a hazai vízellátás jelentős átalakulásával képzelhető el, azaz, ha a folyóinktól távolabb eső és jelenleg rétegvízbázist használó területeket is parti szürt vízzel látjuk el. Azonban számos olyan tényező merül fel, amely a korábban számolt kapacitást negatívan befolyásolhatja. A klímaváltozás, vagy a folyók hidromorfológiai változásai indokolják a vízbázis-diagnosztika 
felülvizsgálatát, valamint korszerübb módszerek alkalmazását.[10] Ez azért is lenne fontos lépés, mert a jelenlegi, védelemben tartási fázisban a monitoring adatok gyüjtésén kívül semmi említésre méltó tevékenység nem történik. Több érzékeny vízbázisunk védelembe helyezése pedig le sem zárult. Hasonló a helyzet a távlati vízbázisok esetében is, amelyek jelenleg csupán vizsgálati és modellezési eredményekre támaszkodó kijelölések, ezeken a területeken a védelembe helyezésen kívül más elökészület nem történt. E vízbázisok üzembe helyezése hosszadalmas folyamat, így csupán feltételes stratégiai tartaléknak tekinthetők és természetesen esetükben is számításba kell venni az éghajlatváltozás hatásait.[11] Fontosnak tartom mind az üzemelö, mind pedig a távlati parti szürésü vízbázisok esetében az elérhető kapacitás és a kitermelhető víz minőségének rendszeres felülvizsgálatát, figyelembe véve az esetlegesen bekövetkező környezeti változásokat, valamint az elérhető méréstechnika pontosságának növekedését.

Nem kevésbé lenne fontos foglalkoznunk a mederoldali védelemmel is. Az egyes védőövezetek határait több helyen jelzik táblák, ám a vízbázisok folyó felöli oldalán semmi nem utal arra, hogy védett területről van szó. A térképeken a folyó felszínére rajzolt védőidomhatárok csupán modellezés eredményei, pontos szivárgás-vizsgálat elöírásszerüen és vízbázisonként nem történt.

Szívesen hangoztatjuk, hogy Magyarország „,víznagyhatalom”. Ez azonban csak addig igaz, amíg rendelkezésünkre álló vízkészleteinket nem tekintjük magától értetődő és múlhatatlan adottságnak. Kiemelt figyelmet kell fordítanunk vízbázisaink védelmére, az eddigi lépések felülvizsgálatára és folytatására, hogy évtizedek múlva is Európa egyik legjobb vízellátottságú országa legyünk.

\section{FELHASZNÁLT IRODALOM}

[1] HISCOCK, K.M., GRISCHEK, T.: Attenuation of groundwater pollution by bank filtration. Journal of Hydrology, 266. 139-144.o. 2002.

[2] 123/1997. (VII. 18.Korm. rendelet a vizbázisok, a távlati vízbázisok, valamint az ivóvizellátást szolgáló vizilétesitmények védelméröl

[3] KÁRMÁN K.: A parti szürésü vizbázisok és jelentőségük; Magyar Tudomány 174. 11. 1300-1306.o. 2013.

[4] Központi Statisztikai Hivatal: A felszín alóli víztermelés víztípusok szerint (1985-) http:// www.ksh.hu/docs/hun/xstadat/xstadat_eves/i_uw003.html (letöltve: 2018.05.08.

[5] BEREK T.: A vízbiztonsági tervezés szerepe a fenntartható vízgazdálkodásban. Müszaki Katonai Közlöny 26. 32-48.o. 2016.

[6] A szerző felvétele

[7] ROTÁRNÉ SZ. Á., HOMOLYA E., SELEMCI P.: A klímaváltozás hatása az ivóvízbázisokra - kutatási jelentés Magyar Földtani és Geofizikai Intézet 2015.

[8] FÖLDI L.: A klímaváltozás által jelentkezö új kihívások a kritikus infrastruktúra védelmében In: Horváth Attila (szerk.) Fejezetek a kritikus infrastruktúra védelemből: kiemelten a közlekedési alrendszer. 268-280.o. Magyar Hadtudományi Társaság, Budapest, 2013.

[9] Országos Vízügyi Főigazgatóság: 2. Vizgyüjtő-gazdálkodási Terv, 2015. 
[10] SOMLYÓDY L., NOVÁKY B., SIMONNFY Z.,: Éghajlatváltozás, szélsőségek és vízgazdálkodás In: "Klíma-21" füzetek, ISSN 1218-5329, 2010. 61., 15-32. o.

[11] HEGEDÜS H.: A Duna vizgyüjtö területének hazai szakasza az éghajlatváltozás tükrében In: BEREK $\mathrm{T}$. et al. (szerk.) Adaptációs lehetőségek az éghajlatváltozás következményeihez a közszolgálat területén 158-222. o. Budapest, ISBN 978-963-498027-8, (2019) 